\title{
Kimberley marine biota. Historical data: soft corals and sea fans (Octocorallia)
}

\author{
Monika Bryce ${ }^{1,2^{*}}$ and Alison Sampey ${ }^{1}$ \\ 1 Department of Aquatic Zoology, Western Australian Museum, Locked Bag 49, Welshpool DC, \\ Western Australia 6986, Australia. \\ ${ }^{2}$ Queensland Museum, PO Box 3300, South Brisbane BC, Queensland 4101, Australia. \\ * Email: monika.bryce@museum.wa.gov.au
}

\begin{abstract}
The Kimberley region is a vast resource-rich area with huge conservation values. In terms of its marine resources, knowledge of soft coral biodiversity is rudimentary. An extensive data compilation of Kimberley octocoral species housed in three Australian natural science collections was undertaken by the Western Australian Museum. This historic species diversity dataset provides baseline knowledge for ongoing and future soft coral investigations in the region. Nearly $80 \%$ of the data was excluded from the present study due to insufficient identification of the collections, with a total of only 63 species being recognised. Based on this limited dataset the overall fauna composition was found to be typical of coral reefs throughout the tropical Indo-Pacific region at shallow depths. More comprehensive taxonomic resolution of existing collections and more extensive surveys of marine habitats in the Kimberley region are necessary to gain a clearer understanding of soft coral biodiversity and abundance, and the uniqueness or commonality of these marine genetic resources within the context of the Indo-Pacific marine fauna.
\end{abstract}

KEYWORDS: natural history collections, baseline, species inventory, Kimberley Marine Bioregion, biodiversity, Octocorals, Alcyonacea

\section{INTRODUCTION}

Natural history collection datasets have been shown to be important sources of baseline biodiversity information to inform conservation and environmental management decisions (Pyke and Ehrlich 2010). The marine environments of the Kimberley region of Australia are currently of interest with tension between areas of high natural conservation values and increased industrial development, including proposed oil and gas reserves (Department of Environment and Conservation 2009). Baseline data are needed to 'characterise the assets' in the region (Wood and Mills 2008), and identify spatial gaps in our inventories as well as improve taxonomic resolution of existing collections.

The Western Australian Museum (WAM) and other Australian natural history institutions have undertaken biodiversity surveys of species in the Kimberley marine environment, but much of this information is either unpublished or published in specialist taxonomic literature, so is not always readily accessible to researchers and managers. Wilson (2014) has reviewed the habitats and historical background of the Kimberley Project Area. Here we report on the current status of the soft coral biodiversity of the Project Area.

Soft corals and sea fans are octocorals within the Order Alcyonacea, with 90 genera and 23 families described from the tropical Indo-Pacific. Octocorals contribute little to the formation of limestone reef structure, but nevertheless are an important component of reef ecosystems (Fabricius and Alderslade 2001). Soft corals are found worldwide, and occur commonly in all reef habitats from the intertidal to abyssal depths. They form a major component of the marine benthos and can be the dominant life form. Nevertheless, they are often neglected in surveys, despite their important ecosystem function as filter feeders, generally due to their difficult taxonomy and the low number of experts capable of identifying octocorals.

Soft corals have received little collecting effort in Western Australian waters, and even less in the Kimberley marine environment, with few historical voucher collections - the most prominent being a collection made during the Swedish Möberg Scientific Expedition (1910-1913), from a pearl 
bank off Cape Jaubert in the southern Kimberley Bioregion. From this collection, Broch (1916) described 25 octocoral species, including 14 new species.

No further large scale soft coral collecting occurred in Western Australia for several decades and identification lists for Kimberley waters have been presented in only three reports (Marsh 1986, 1993; Keesing et al. 2011). The marine faunal surveys of Ashmore Reef and Cartier Island by the Northern Territory Museum (now Museum and Art Gallery of the Northern Territory) in 1986 and 1987 include collections of octocorals from Ashmore Reef (Marsh 1993). The faunal survey by Marsh (1986) documents only a few octocoral species from the North West Shelf Bioregion (Rowley Shoals) and the Oceanic Shoals Bioregion (Scott Reef and Seringapatam Reef). A small collection of soft corals was also made from Ashmore Reef in 1997, but this was incidental to collections made of hard corals (Griffith 1997). Thirty nine specimens were collected and 32 species from 16 genera recorded (Griffith 1997). Soft corals were a prominent part of the reef community at Ashmore Reef, particularly in the lagoon and on the north-west reef slope (Griffith 1997). Keesing et al. (2011) reported on soft corals along the southern extent of the Dampier Peninsula in the southern Kimberley Bioregion.

\section{AIM}

The aim of this paper is to report the shallow water $(<30 \mathrm{~m})$ soft coral species in the Kimberley Project Area of Australia as verified by voucher specimens lodged in museum collections and to provide commentary on diversity trends, taxonomic and collection gaps of this faunal group. This historical synthesis is intended to provide baseline information for the ongoing marine biodiversity survey program, the Woodside Collection Project (Kimberley) 2008-2015 by WAM, and future surveys in the region.

\section{METHODS}

\section{STUDY AREA, TAXONOMIC AND COLLECTION SCOPE}

The Project Area encompasses an area west and north of the Kimberley coast (south of Broome to the Western Australia-Northern Territory border) extending beyond the $1000 \mathrm{~m}$ bathymetric contour, with the coastline forming a natural inshore boundary, as shown in Figure 1 (see Sampey et al. 2014 for a full description of the study area).

Recorded data of the order Alcyonacea (soft corals and sea fans) are included in this paper. In addition, we added records of the closely related order Helioporacea (blue coral, Heliopora coerulea (Pallas, 1766). Both orders belong to the subclass Octocorallia. Octocorals identified to species level in Keesing et al. (2011) are reported here, but otherwise these data are not incorporated in this historical analysis as it was published after data collation (Sampey et al. 2014).

The methodology follows that outlined by Sampey et al. (2014). Soft coral data for the Project Area were sourced from the collection databases of WAM, Australian Museum (AM) and Museum and Art Gallery of the Northern Territory (MAGNT) and the species lists published in two reports (Marsh 1986, 1993). In addition, records of Heliopora coerulea (Pallas, 1766) and Tubipora musica Linnaeus, 1758 were included from one unpublished report (Marsh 1992) and one published report (McKinney 2009). Only specimens identified to species (or operational taxonomic units, OTU) were included. This paper deals with baseline data, and as such, detail to species level was considered important as all museum identifications were assumed to be with authority (Sampey et al. 2014).

Species names represent a hypothesis, which is subject to change as new information (morphology, genetic, behaviour, distribution ranges) is discovered (Gaston and Mound 1993). The species names and taxonomic placement of the records in the dataset were checked with the aim of presenting the currently accepted name, but the specimens were not re-examined for this study (Sampey et al. 2014). Species names were checked for current taxonomic placement and validity using a variety of online resources (Appeltans et al. 2010; ABRS 2011; Rees et al. 2011). There is no Zoological Catalogue of Australia for soft corals and the Australian Faunal Directory (ABRS 2011) for soft corals is sparse and incomplete. Higher taxonomy and generic placement follows Fabricius and Alderslade (2001).

\section{SPATIAL INFORMATION, COLLECTION DETAILS AND MAPPING}

As detailed in Sampey et al. (2014) data from all sources were collated into a single database. The location and collecting details were checked and verified, and the location of the specimen records were visualised using ARCGIS v9, ArcMap v9.3. Maps of species richness and sampling effort were generated for each main location. The full list of locations, latitude and longitude and other relevant collection information is provided in Table 2 in Sampey et al. (2014). 


\section{BIOGEOGRAPHIC AND HABITAT CODING}

Species were coded for their known habitat and biogeographic ranges: see Sampey et al. (2014) for a full description of these codes. A habitat code was recorded for species based on their known habitat and annotated with a superscript $i$ for intertidal zone $\left(^{(}\right)$or superscript $\mathrm{s}$ for subtidal zone (s) attached to $\mathrm{H}$ or $\mathrm{S}$ for hard or soft substrates respectively. The following biogeographic codes were used:

- Indo-Australian (IA). Found throughout Australian and Indonesian waters; may extend to the Philippines and, for some species, Japan.

- Indian Ocean (IO). Restricted to the Indian Ocean.

- Indo-West Pacific (IWP). Found throughout the Red Sea, Indian and Western Pacific Oceans.

- Indo-Pacific (IP). Found throughout the Red Sea, Indian Ocean and throughout the Pacific Ocean.

\section{RESULTS}

\section{NUMBER OF SPECIMENS IN COLLECTIONS}

A total of 647 soft coral specimen lots were found (Sampey et al. 2014; Table 1). A 'lot' may represent one to many individuals from the same site. Most of the lots were located in WAM (372 lots) and the MAGNT (273 lots). One hundred and forty of the specimen lots were identified to species or OTUs and able to be interpreted as representing a single morphospecies (Table 1). Many lots (507, $78 \%$ ) were excluded from the present dataset due to insufficient taxonomic resolution. The oldest record in the databases for a soft coral from the Project Area was Melithaea ochracea (Linnaeus, 1785) collected from Cockatoo Island in 1963.

TABLE 1 Number of specimen lots of Project Area soft corals housed in Australian collections. Included are those lots identified to species or OTU, able to be distinguished as a separate species, and excluded are those lots incompletely identified.

\begin{tabular}{lll} 
Collection & Included & Excluded \\
\hline AM & 2 & 0 \\
MAGNT & 29 & 244 \\
WAM & 109 & 263 \\
Total & $\mathbf{1 4 0}$ & $\mathbf{5 0 7}$ \\
\hline
\end{tabular}

\section{SPECIES RICHNESS AND COLLECTING EFFORT}

A total of 53 soft coral species were recorded in the dataset and a further 10 lots were identified to OTU and treated as individual 'morphospecies'. Therefore, 63 species of soft corals were represented in the Kimberly Project Area, 19 from the inshore and 57 from the offshore continental edge atolls (Table 2). No collection of soft corals has been undertaken at Browse Island, the only midshelf island in this region (Figure 1).

Soft corals have been recorded from 32 locations in the Project Area (Tables 3 and 4, Figure 1). Species richness varied considerably from 44 species at Ashmore Reef to one at each of 14 inshore sites (Table 4, Figure 2).

This variation is partially due to a variable sampling effort between the collection sites - with seven collecting events at Ashmore Reef and only one to three collecting events at each of the other 31 locations (Table 4, Figure 3). Undoubtedly there are many other deterministic and stochastic processes that could explain observed heterogeneity between these octocoral communities, which will require detailed studies of the fauna in the future.

For the present, based on included data, we are able to suggest that octocoral species richness was generally higher at the six offshore sites (Ashmore, Scott, Seringapatam, Clerke and Mermaid Reefs and Cartier Island) than at the inshore locations (Tables 2 and 4, Figure 2). For 14 of the Kimberley inshore sites there was a single species of soft coral recorded from a single collecting event (Table 4, Figure 3).

\section{BIOGEOGRAPHY AND HABITATS}

The majority of the species inhabited subtidal hard substrates (58 species). Two species, Tubipora musica Linnaeus, 1758 and Heliopora coerulea (Pallas, 1766) are known to occur on both intertidal and subtidal hard substrates. Four species, Solenocaulon grayi Studer, 1878, Ctenocella pectinata (Pallas, 1766), Junceella fragilis (Ridley, 1884) and Hicksonella princeps Nutting, 1910 are known to occur subtidally on both hard and soft substrates (Table 2). The majority of the species were wide ranging IWP or IP at both inshore and offshore locations (Tables 2 and 3). There were no locally endemic species of soft coral recorded in this dataset.

\section{DISCUSSION}

The importance of historical museum collections is well outlined by Hoeksema et al. (2011) and Hooper and Ekins (2004). Well maintained, taxonomically resolved zoological collections are important tools providing historical baseline biodiversity and ecological 
TABLE 2 Species of octocorallia (Alcyonacea, Helioporacea) recorded from the Project Area with habitat and biogeographic codes. Habitat code: $\mathrm{H}$, hard substrate; $\mathrm{S}$, soft substrate; (i), intertidal zone; (s), subtidal zone. Biogeographic codes: IA, Indo-Australian; IO, Indian Ocean; IWP, Indo-West Pacific; IP, Indo-Pacific. *additional species recorded in Keesing et al. (2011).

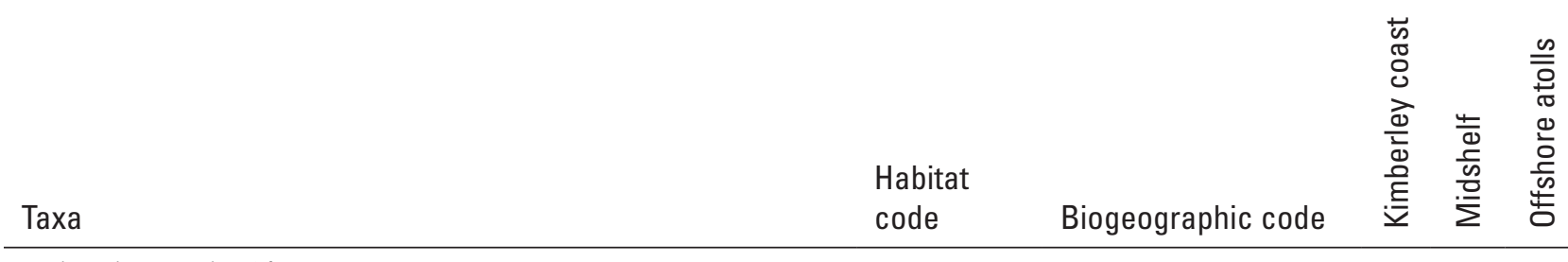

\section{Suborder: Stolonifera}

Family: Clavulariidae

Clavularia sp.

$\mathrm{H}^{\mathrm{s}}$

Family: Coelogorgiidae

Coelogorgia sp.

$\mathrm{H}^{\mathrm{s}}$

Family: Tubiporidae

Tubipora musica Linnaeus, 1758

$\mathrm{H}^{\text {is }} \quad$ IP

Suborder: Alcyoniina

Family: Alcyoniidae

*Lobophytum crassum von Marenzeller, 1886

Lobophytum crebriplicatum von Marenzeller, 1886

Lobophytum pauciflorum (Ehrenberg, 1834)

Minabea aldersladei Williams, 1992

Sarcophyton birkelandi Verseveldt, 1978

Sarcophyton buitendijki Verseveldt, 1982

Sarcophyton cinereum Tixier-Durivault, 1946

Sarcophyton crassocaule Moser, 1919

Sarcophyton crassum Tixier-Durivault, 1946

Sarcophyton ehrenbergi von Marenzeller, 1886

Sarcophyton elegans Moser, 1919

Sarcophyton glaucum (Quoy \& Gaimard, 1833)

Sarcophyton infundibuliforme Tixier-Durivault, 1958

Sarcophyton cf. latum (Dana, 1846)

Sarcophyton portentosum Tixier-Durivault, 1970

Sarcophyton roseum Pratt, 1903

Sarcophyton spinospiculatum Alderslade \& Shirwaiker, 1991

$\begin{array}{ll}\mathrm{H}^{\mathrm{s}} & \text { IWP } \\ \mathrm{H}^{\mathrm{s}} & \text { IWP } \\ \mathrm{H}^{\mathrm{s}} & \text { IWP } \\ \mathrm{H}^{\mathrm{s}} & \text { IP } \\ \mathrm{H}^{\mathrm{s}} & \text { IP } \\ \mathrm{H}^{\mathrm{s}} & \text { IWP } \\ \mathrm{H}^{\mathrm{s}} & \text { IP } \\ \mathrm{H}^{\mathrm{s}} & \text { IP } \\ \mathrm{H}^{\mathrm{s}} & \text { IP } \\ \mathrm{H}^{\mathrm{s}} & \text { IWP } \\ \mathrm{H}^{\mathrm{s}} & \text { IP } \\ \mathrm{H}^{\mathrm{s}} & \text { IWP } \\ \mathrm{H}^{\mathrm{s}} & \text { IO } \\ \mathrm{H}^{\mathrm{s}} & \text { IP } \\ \mathrm{H}^{\mathrm{s}} & \text { IP } \\ \mathrm{H}^{\mathrm{s}} & \text { IO } \\ \mathrm{H}^{\mathrm{s}} & \text { IO } \\ \mathrm{H}^{\mathrm{s}} & \text { IWP } \\ \mathrm{H}^{\mathrm{s}} & \text { IP } \\ \mathrm{H}^{\mathrm{s}} & \text { IWP } \\ \mathrm{H}^{\mathrm{s}} & \text { IP } \\ \mathrm{H}^{\mathrm{s}} & \text { IWP } \\ \mathrm{H}^{\mathrm{s}} & \text { IP } \\ \mathrm{H}^{\mathrm{s}} & \text { IP } \\ \mathrm{H}^{\mathrm{s}} & \text { IP } \\ \mathrm{H}^{\mathrm{s}} & \text { IWP } \\ \mathrm{H}^{\mathrm{s}} & \end{array}$

Sarcophyton stellatum Kükenthal, 1910

Sarcophyton tenuispiculatum (Thomson \& Dean, 1931)

Sarcophyton trocheliophorum von Marenzeller, 1886

*Sinularia cf. acuta Manuputty \& van Ofwegen, 2007

Sinularia brassica May, 1898

Sinularia densa (Whitelegge, 1897)

Sinularia firma Tixier-Durivault, 1970

Sinularia flexibilis (Quoy and Gaimard, 1833)

Sinularia leptoclados (Ehrenberg, 1834)

Sinularia maxima Verseveldt, 1971

IP 


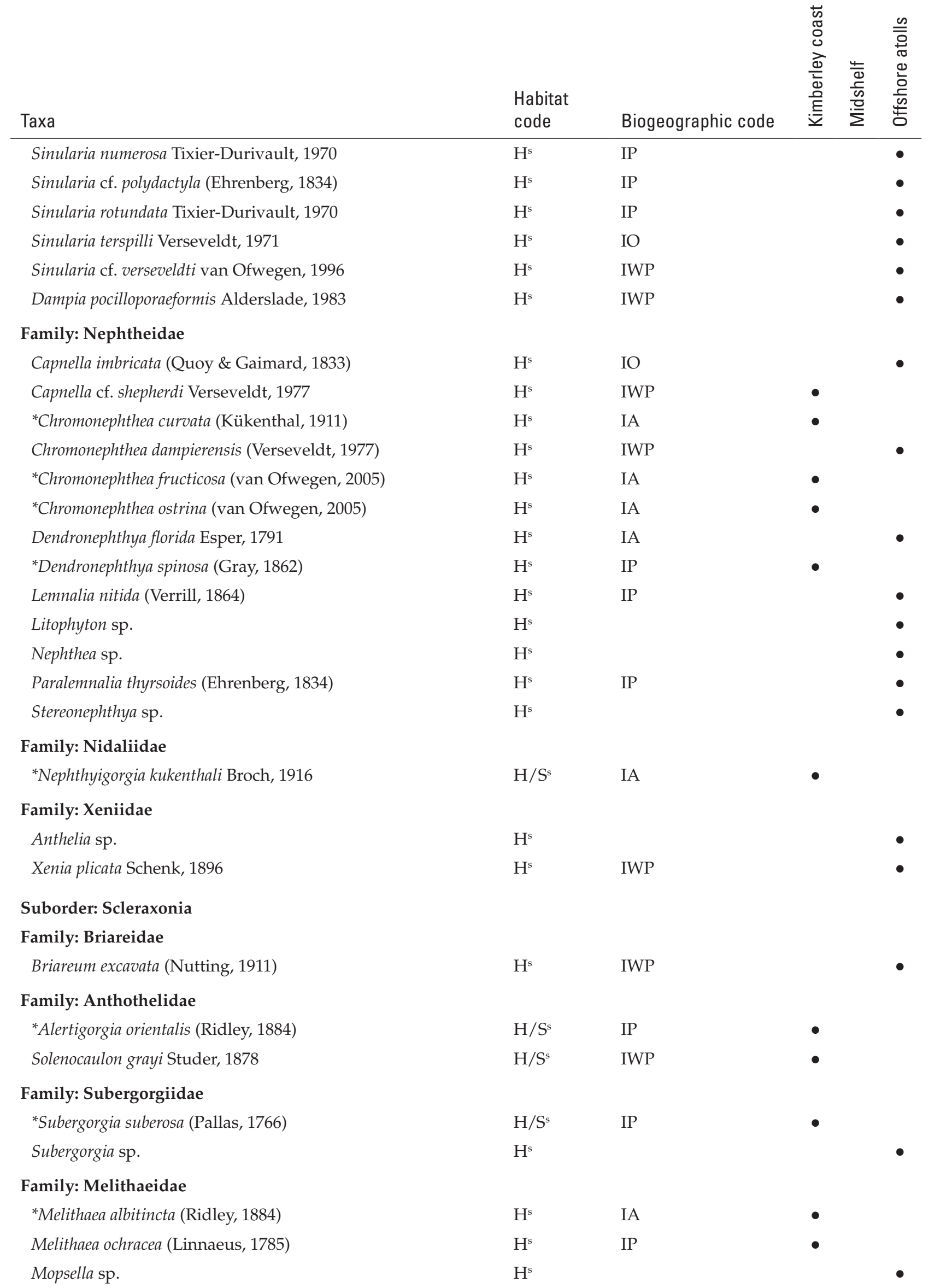




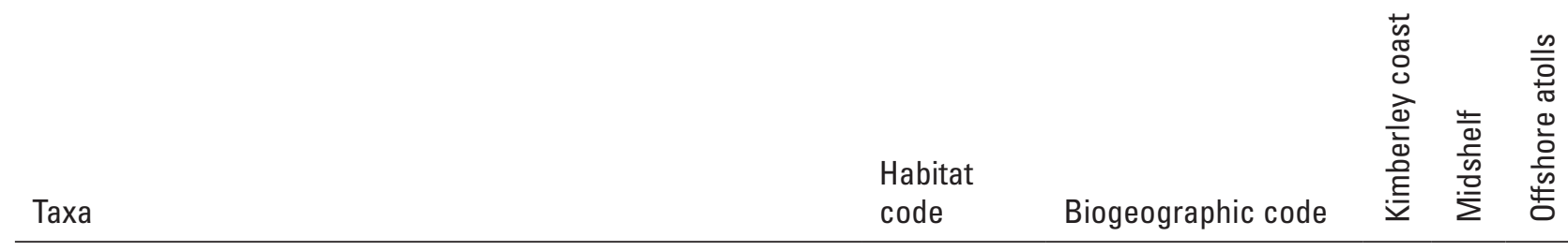

\author{
Suborder: Holoxonia \\ Family: Acanthogorgiidae \\ Muricella sp.
}

\section{Family: Plexauridae \\ Echinogorgia flabellum (Esper, 1791) \\ ${ }^{*}$ Echinogorgia reticulata (Esper, 1791) \\ ${ }^{*}$ Menella simplex (Kükenthal, 1908) \\ Villogorgia sp. \\ *Paraplexaura cf. mikrodentata \\ *Paraplexaura cf. rigida \\ *Paraplexaura multispinosa}

\section{Family: Gorgoniidae}

Hicksonella princeps Nutting, 1910

Pinnigorgia flava (Nutting, 1910)

Pinnigorgia perroteti (Stiasny, 1940)

Pinnigorgia platystoma (Nutting, 1910)

${ }^{*}$ Pseudopterogorgia australiensis (Ridley, 1884)

Pseudopterogorgia sp.

${ }^{*}$ Rumphella aggregata (Nutting, 1910)

Rumphella sp.

\section{Suborder: Calcaxonia \\ Family: Ellisellidae \\ Ctenocella pectinata (Pallas, 1766) \\ *Dichotella gemmacea (Milne Edwards \& Haime, 1857) \\ Junceella fragilis (Ridley, 1884)}

Family: Isididae

Isis hippuris Linnaeus, 1758

Order: Helioporacea

Family: Helioporidae
$\mathrm{H}^{\mathrm{s}}$

$\begin{array}{ll}\mathrm{H}^{\mathrm{s}} & \text { IWP } \\ \mathrm{H}^{\mathrm{s}} & \text { IP } \\ \mathrm{H}^{\mathrm{s}} \mathrm{s} & \mathrm{IP} \\ \mathrm{H}^{\mathrm{s}} & \end{array}$

$\begin{array}{ll}\mathrm{H} / \mathrm{S}^{\mathrm{s}} & \text { IP } \\ \mathrm{H}^{\mathrm{s}} & \text { IWP } \\ \mathrm{H}^{\mathrm{s}} & \text { IWP } \\ \mathrm{H}^{\mathrm{s}} & \text { IO } \\ \mathrm{H}^{\mathrm{s}} & \text { IA } \\ \mathrm{H}^{\mathrm{s}} & \\ \mathrm{H}^{\mathrm{s}} & \text { IA } \\ \mathrm{H}^{\mathrm{s}} & \end{array}$

$\begin{array}{ll}\mathrm{H} / \mathrm{S}^{s} & \text { IWP } \\ \mathrm{H} / \mathrm{S}^{\mathrm{s}} & \text { IP } \\ \mathrm{H} / \mathrm{S}^{\mathrm{s}} & \mathrm{IP}\end{array}$

$\mathrm{H}^{\mathrm{s}}$

IWP data, as well as determining biotic and human impact on coral reefs. The current knowledge of the Western Australian soft coral fauna remains extremely rudimentary and it is likely many new species exist in unexamined or only partly resolved material held within museum collections.

The majority of species collected in the Project Area are from offshore atolls. Fewer species were identified from the coastal regions, and there is a distinct lack of octocoral knowledge in the midshelf region. Unfortunately, the limited collection effort to date precludes meaningful comparative analyses between regions. WAM is currently undertaking surveys of the region and it is hoped, with increased knowledge and sampling effort, cross shelf community differences and similarities may become apparent. Will a shift in abundance and species composition related to the environmental differences within the taxonomic 


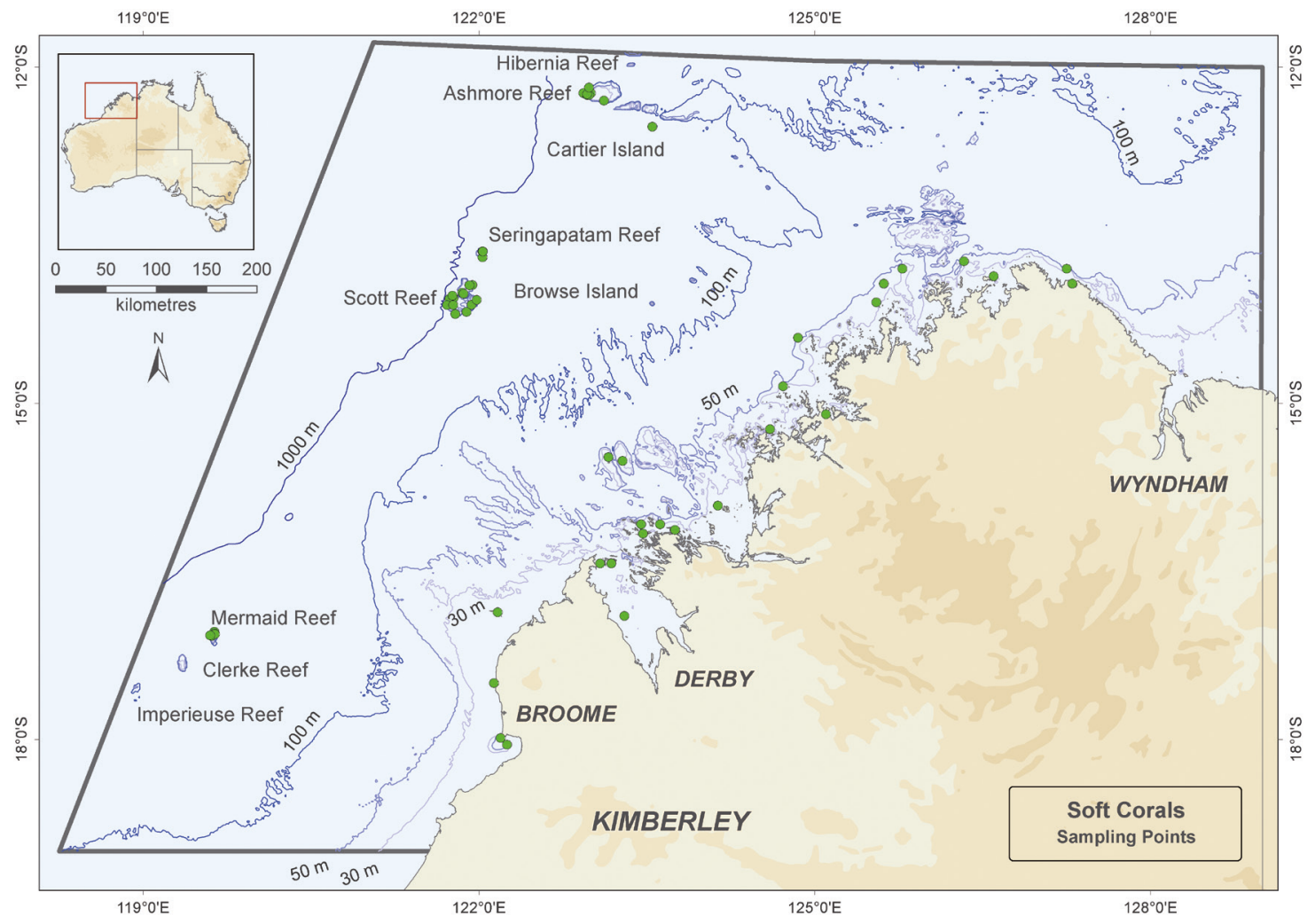

FIGURE 1 Location of records of soft corals in the Project Area. The Project Area is bounded by the grey box. Map projection: GDA94, Scale: 1:6, 250,000.

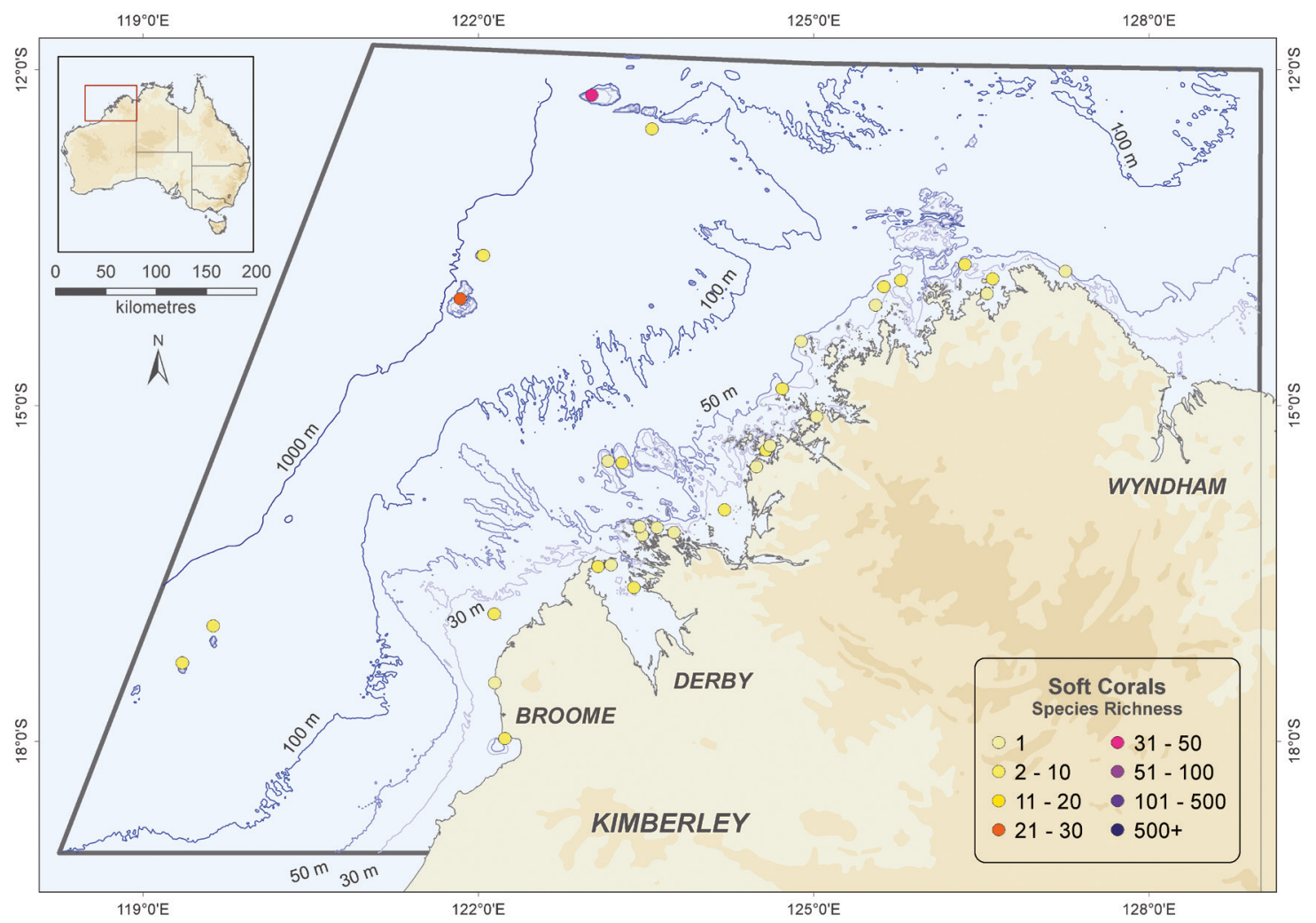

FIGURE 2 Species richness of soft corals for each main location. Map projection: GDA94, Scale: 1:6, $250,000$. 


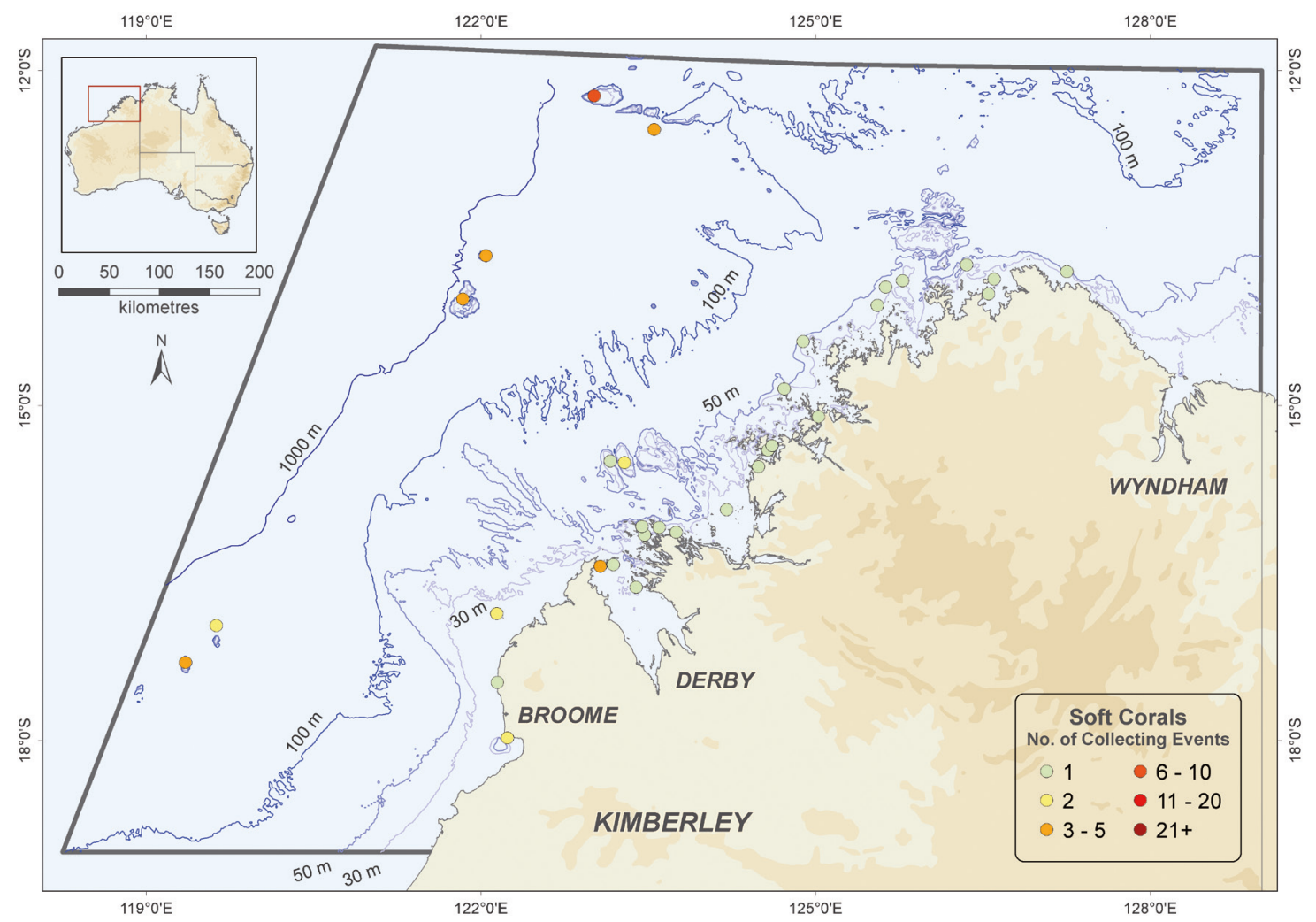

FIGURE 3 Number of collecting events for soft corals at each main location for which there are collections. See Sampey et al. (2014) for details of how this was determined. Map projection: GDA94, Scale: 1:6, 250,000.

groups be realised with the inclusion of more data from current and future surveys? Further research will undoubtedly provide the data to answer this question.

All major groups of soft corals were represented in this synthesis of historical data. In general, the collection reflects a typical Indo-Pacific assemblage for these depths. The majority of the soft corals listed belong to the Alcyoniina group (31 Alcyoniidae, 9 Nephtheidae, 2 Xeniidae), with the genera Sinularia and Sarcophyton being the most common. Holaxonia were represented by nine species, Scleraxonia by five, and Calcaxonia by three.

In general, the Kimberley Project Area octocoral species are associated with hard substrates. This may be related to collecting methods and targeted collection sites. Soft sediments have received comparatively little collection effort and less accessible areas, such as reef overhangs and exposed sites, may not have been sampled. This would explain the lack of smaller, more cryptic, rare and endemic species in the dataset. Another artefact of the octocoral species composition is that
TABLE 3 Number of species within each biogeographic code.

\begin{tabular}{lll} 
Biogeographic code & Inshore & Offshore \\
\hline- & & 13 \\
IA & & 1 \\
IO & 7 & 6 \\
IP & 21 \\
IWP & 12 & 16 \\
Total & 19 & 57 \\
\hline
\end{tabular}

they were, for the most part, collected incidental to collections made for other animal groups by non-experts in the field. Only large and obvious octocoral specimens would have been sampled, with less typical forms being overlooked.

Keesing et al. (2011) reported 28 OTUs and 20 species of octocorals, 18 formerly not identified in our historic data material. This 
TABLE 4 Species richness and number of collection events at each location.

\begin{tabular}{|c|c|c|}
\hline Location & $\begin{array}{l}\text { Species } \\
\text { richness }\end{array}$ & $\begin{array}{l}\text { No. collecting } \\
\text { events }\end{array}$ \\
\hline Adele Island & 1 & 1 \\
\hline Ashmore Reef & 44 & 7 \\
\hline Augustus Island & 3 & 2 \\
\hline Broome & 3 & 2 \\
\hline Camden Sound & 1 & 1 \\
\hline Careening Bay & 1 & 1 \\
\hline Cartier Island & 10 & 3 \\
\hline Cassini Island & 2 & 1 \\
\hline Churchill Reef & 2 & 1 \\
\hline Clerke Reef & 4 & 2 \\
\hline Cockatoo Island & 1 & 1 \\
\hline Condillac Island & 1 & 1 \\
\hline James Price Point & 1 & 1 \\
\hline Jones Island & 2 & 1 \\
\hline King Sound & 2 & 1 \\
\hline Koolan Island & 1 & 1 \\
\hline Lacepede Islands & 3 & 2 \\
\hline Lesueur Island & 1 & 1 \\
\hline Long Reef & 2 & 1 \\
\hline Lord Island & 1 & 1 \\
\hline Mermaid Reef & 2 & 1 \\
\hline Montgomery Reef & 4 & 3 \\
\hline One Arm Point & 5 & 3 \\
\hline Powerful Island & 1 & 1 \\
\hline Robroy Reefs & 1 & 1 \\
\hline Scorpion Island & 2 & 1 \\
\hline Scott Reef & 21 & 4 \\
\hline Seringapatam Reef & 4 & 3 \\
\hline Sheep Island & 1 & 1 \\
\hline Sunday Island & 1 & 1 \\
\hline Vansittart Bay & 1 & 1 \\
\hline Woodward Island & 2 & 1 \\
\hline
\end{tabular}

represents a considerable increase in soft coral biodiversity knowledge. However, that report stated that no conclusion could be made about the representativeness of the collection to expected species diversity due to the general lack of knowledge of octocorals in the Kimberley Project Area.

Comprehensive sampling and data analysis of Project Area marine habitats for soft corals, amongst other marine invertebrates, has not been undertaken. Nevertheless, the present synthesis of a subset of existing soft coral data will facilitate future surveys of the area to test some of the rudimentary hypotheses discussed here. Taxonomic, as well as non-taxonomic, aspects of octocoral biology need to be investigated, including environmental parameters, sampling effort and methodology, habitat types and geomorphic zones - together providing evidence to measure the ecological drivers influencing octocoral biodiversity of the Kimberley Project Area.

\section{ACKNOWLEDGEMENTS}

We thank our taxonomic colleagues, Jane Griffith and Loisette Marsh who collected most of the soft coral specimens contained in this dataset. Phil Alderslade, Jane Griffith and Loisette Marsh identified the majority of the soft corals. Special thanks to Phil Alderslade for his critical review of the geographical distribution of the soft coral species in this manuscript and helpful discussions about taxonomy.

\section{REFERENCES}

ABRS (2011). 'Australian Faunal Directory'. Australian Biological Resources Study: Canberra, Australia; online at http://www.environment.gov.au/ biodiversity/abrs/online-resources/fauna/afd/ index.html. Accessed 2008-2011.

Appeltans, W., Bouchet, P., Boxshall, G.A., Fauchald, K., Gordon, D.P., Hoeksema, B.W., Poore, G.C.B., van Soest, R.W.M., Stöhr, S., Walter, T.C. and Costello, M.J. (eds) (2010). World register of marine species; online at http://www.marinespecies.org. Accessed 2008-2011.

Broch, H. (1916). Results of Dr. E. Mjöbergs Swedish scientific expedition to Australia 1910-1913. XI. Alcyonarien. Kunglia Svenska Vetenskapsakademiens Handlingar 52(11): 1-52.

Department of Environment and Conservation (2009). Protecting the Kimberley. A synthesis of scientific knowledge to support conservation management in the Kimberley region of Western Australia. Department of Environment and Conservation: Perth.

Fabricius, K. and Alderslade, P. (2001). Soft corals and sea fans: a comprehensive guide to the tropical shallow water genera of the central-west Pacific, the Indian Ocean and the Red Sea. Australian Institute of Marine Science: Townsville, Queensland.

Gaston, K.J. and Mound, L.A. (1993). Taxonomy, hypothesis testing and the biodiversity crisis. Proceedings: Biological Sciences 251(1331): 139-142.

Griffith, J. (1997). The corals collected during September/ October 1997 at Ashmore Reef, Timor Sea. Parks Australia: Canberra. Unpublished report.

Hoeksema, B.W., van der Land, J., van der Meij, S.E.T., van Ofwegen, L.P., Reijnen, B.T., van Soest, R.W.M. 
and de Voogd, N.J. (2011). Unforseen importance of historical collections as baselines to determine biotic changes of coral reefs: the Saba Bank. Marine Ecology 32: 135-141.

Hooper, N.A.J and Ekins, M. (2004). Collation and validation of museum collection databases related to the distribution of marine sponges in northern Australia. Technical reports of Queensland Museum 2: 1-90; online at http://www.network.qm.qld.gov.au/ About+Us/Publications/Memoirs+of+the+Queensla nd+Museum/Technical+reports.

Keesing, J.K., Irvine, T.R., Alderslade, P., Clapin, G., Fromont, J., Hosie, A.M., Huisman, J.M., Phillips, J.C., Naughton, K.M., Marsh, L.M., Slack-Smith, S.M., Thomson, D.P. and Watson, J.E. (2011). Marine benthic flora and fauna of Gourdon Bay and the Dampier Peninsula in the Kimberley region of north-western Australia. Journal of the Royal Society of Western Australia 94: 285-301.

Marsh, L.M. (1986). Faunal survey of the Rowley Shoals, Scott Reef and Seringapatam Reef, north-western Australia, Part III: Cnidaria, other than reef-building corals. Records of the Western Australian Museum Supplement 25: 37-38.

Marsh, L.M. (1992). Part II. Scleractinian and other hard corals (pp. 15-22). In: Morgan, G.J. (ed.), Survey of the aquatic fauna of the Kimberley Islands and reefs, Western Australia. Western Australian Museum: Perth. Unpublished report.
Marsh, L.M. (1993). Cnidaria, other than reef-building corals, of Ashmore Reef and Cartier Island. Records of the Western Australian Museum Supplement 44: 21-22.

McKinney, D. (2009). A survey of the scleractinian corals at Mermaid, Scott and Seringapatam Reefs, Western Australia. Records of the Western Australian Museum Supplement 77: 105-144.

Pyke, G.H. and Ehrlich, P.R. (2010). Biological collections and ecological/environmental research: a review, some observations and a look to the future. Biological Reviews 85(2): 247-266.

Rees, A.J.J., Yearsley, G.K., Gowlett-Holmes, K. and Pogonoski, J. (2011). Codes for Australian aquatic biota (online version). CSIRO Marine and Atmospheric Research: Hobart, Australia; online at http://www.cmar.csiro.au/caab/. Accessed 2008-2011.

Sampey, A., Bryce, C., Osborne, S. and Miles, A. (2014). Kimberley marine biota: Historical data: introduction and methods. Records of the Western Australian Museum Supplement 84: 19-43.

Wilson, B.R.W (2014). Kimberley marine biota. History and environment. Records of the Western Australian Museum Supplement 84: 1-18.

Wood, M. and Mills, D. (2008). A turning of the tide: science for decisions in the Kimberley-Browse marine region. Western Australian Marine Science Institute: Perth.

MANUSCRIPT RECEIVED 27 JUNE 2013; ACCEPTED 12 SEPTEMBER 2014 